\title{
Utilization of waste gypsum in fertilizer production
}

\author{
Przemysław Malinowski ${ }^{1}$, Mieczysław Borowik ${ }^{2}$, Wiesław Wantuch ${ }^{3}$, Leszek Urbańczyk ${ }^{3}$, \\ Michał Dawidowicz ${ }^{2}$, Andrzej Biskupski ${ }^{2}$
}

\author{
${ }^{1}$ University of Applied Sciences in Nysa, ul. Armii Krajowej 7, 48-300 Nysa, Poland \\ ${ }^{2}$ Fertilizers Research Institute, al. 1000-lecia Państwa Polskiego 13 A, 24-110 Puławy, Poland \\ ${ }^{3}$ Chemical Company Alwernia S.A., ul. K. Olszewskiego 25, 32-566 Alwernia, Poland \\ "Corresponding author: e-mail: przemyslaw.malinowski@pwsz.nysa.pl
}

\begin{abstract}
The results of the study regarding utilization of the waste gypsum formed as a by-product during the production of the magnesium sulphate from dolomite have been presented. The use of this waste have been proposed for the production of granulated multi-component fertilizers containing $25 \% \mathrm{~N} ; 8 \% \mathrm{~S} ; 14 \% \mathrm{CaO}$ and $3.5 \% \mathrm{MgO}$. In the process of fertilizer production, the urea which will be bounded with the calcium and magnesium sulphate from the waste in the form of adducts of $\mathrm{CaSO}_{4} \cdot 4 \mathrm{CO}\left(\mathrm{NH}_{2}\right)_{2}$ and $\mathrm{MgSO}_{4} \cdot \mathrm{CO}\left(\mathrm{NH}_{2}\right)_{2} \cdot 3 \mathrm{H}_{2} \mathrm{O}$ will be the source of nitrogen in the fertilizer. It has been stated on the basis of the laboratory tests that the fertilizer with the assumed composition can be obtained by means of granulation of the raw material pulp, along with the dried and ground product return. The possibility of the production of the fertilizer with good physical properties according to the assumed concept has been confirmed in the pilot scale.
\end{abstract}

Keywords: fertilizer, adduct, gypsum, waste, by-product, magnesium sulphate.

\section{INTRODUCTION}

One of the main products of Chemical Company Alwernia S.A. is magnesium sulphate. The production raw materials include caustic magnesite and sulphuric acid. In search of a possibility to reduce the production costs and increase the competitiveness of the product, Alwernia S.A. decided to examine the possibility of the production of magnesium sulphate from alternative raw materials. One of such raw materials is dolomite. Since thereby $\mathrm{Ca}$ is included with the educts production of magnesium sulphate from such a raw material it is connected with the formation of substantial amounts of the by-product, i.e. gypsum. Currently, as a result of the pro-ecological policy of Alwernia S.A., there are only waste-free technologies conducted or technologies related to each other in such a manner that the waste formed in one production constitutes a raw material for another process. Analyzing the possibility of the modification of the existing technology of the production of magnesium sulphate, apart from the technological aspects resulting from the change of the raw material, a method of utilization of the generated waste must also be found. Wastes from different branches of industry are frequently used as raw materials for the production of fertilizers ${ }^{1-4}$. Several years ago Alwernia S.A. launched the production of granulated fertilizers where the by-products containing valuable fertilizing components are managed, including those from the production of magnesium sulphate ${ }^{4}$. Taking into account the form and composition of the gypsum formed at the production of magnesium sulphate from dolomite as well as the conditions of Alwernia S.A., it seems justified to manage this waste also at the production of the multi-component (N-S-Ca-Mg) granulated fertilizers. The source of nitrogen in the obtained fertilizer would be urea which is frequently used in the process of production of the multi-component fertilizers ${ }^{5}$. In this fertilizer urea could be bounded with the calcium and magnesium sulphates from the waste in the form of adducts of $\mathrm{CaSO}_{4} \cdot 4 \mathrm{CO}\left(\mathrm{NH}_{2}\right)_{2}$ and $\mathrm{MgSO}_{4} \cdot \mathrm{CO}\left(\mathrm{NH}_{2}\right)_{2} \cdot 3 \mathrm{H}_{2} \mathrm{O}^{6}$.

\section{EXPERIMENTAL}

The works on the determination of the manner of management of the waste gypsum included laboratory tests and pilot trials. The laboratory tests were conducted with the use of the laboratory kit for the formation of the process pulps, consisting of an acid-resistant steel reactor, capacity $2 \mathrm{dm}^{3}$, along with a heating mantle equipped with a three-paddle laboratory mixer with an adjustable number of revolutions, IKA Labortechnik type EURO ST-D [Staufen, Germany]. The granulation of the fertilizers at the laboratory site was conducted in the ERWEKA [Heusenstamm, Germany] AMD mixer to which the raw materials in the form of pulp as well as the dried pulp with identical composition were dosed. The pilot scale tests of the process of fertilizers production were conducted with the use of the INS multi-component fertilizers granulation installation ${ }^{7}$. The raw material in the form of pulp was fed with the use of a peristaltic pump to the paddle granulator where the recycle of the dried product was directed. The produced granulate was additionally turned on the granulation pan and then it was directed to the dryer. Having left the dryer, the granulate was segregated on the sieves where part of the right fraction of the product was collected. Undersized and oversized product and a part of the right fraction were recycled to the paddle granulator. The amount of the return directed to the granulator was regulated with the use of a screw feeder (excess amount was withdrawn from the system to a buffer tank and introduced to the system when necessary). After the granulation test, the entire product was withdrawn from the system and divided into fractions (undersize, oversize and right product $2-5 \mathrm{~mm}$ ). For the purpose of the trial there was $120 \mathrm{~kg}$ of the dried product return prepared with changed composition, ground to less than $4 \mathrm{~mm}$. The feed was prepared on the day of trial performance by means of mixing of $50 \mathrm{~kg}$ of the waste gypsum and $37.3 \mathrm{~kg}$ of urea in the reactor.

The composition of the raw materials and products as well as the physical properties of the products (graining, granule hardness, hygroscopicity) were evaluated in ac- 
cordance with the governing standards ${ }^{\mathbf{8}, 9}$. The hardness of fertilizer granules was measured with ERWEKA TBH $200 \mathrm{D}$ apparatus. Every time the $20-30$ granules of diameter 2.5-3.15 mm were used for the measurements. The hygroscopicity of fertilizer samples was assessed with desiccators where sulphuric acid solution of proper concentration providing the assumed relative humidity of air was introduced. Changes in the mass of fertilizer samples exposed to atmospheres with varied relative humidity were measured. The degree of conversion of the urea into the adducts was evaluated with a method based on the difference in the solubility of the free urea and urea bounded into an adduct in n-butanol ${ }^{10}$. n-Butanol is a solvent where free urea would be dissolved but not the one bound into the adduct form. In order to dissolve the unreacted urea, a sample was treated with $\mathrm{n}$ - butanol and then the liquid phase was separated from the sediment. Then the adduct remaining in the sediment was decomposed with water. When liquid phase was separated from the deposit then urea dissolved in water was determined. Simultaneously the total urea content in the sample was determined.

The raw materials employed in the tests included crystalline urea from Nitrogen Plant Kędzierzyn S.A., granulated urea from Nitrogen Plant Puławy S.A. as well as waste gypsum from the production of magnesium sulphate obtained during the industrial trials of production of the magnesium sulphate from dolomite in Alwernia S.A..

\section{DISCUSSION OF RESULTS}

The main component of the waste gypsum is calcium sulphate and it contains also undecomposed dolomite and unwashed magnesium sulphate (Table 1). From the point of view of the fertilizer, the waste gypsum is of interesting composition. It is envisaged that this product can be used for production of the nitrogen-sulphur-calcium fertilizers, additionally enriched with magnesium. The use of the waste gypsum and urea in the quantities resulting from the stoichiometric composition of the adducts with calcium and magnesium sulphates will allow to produce the fertilizer with the following composition: $25 \% \mathrm{~N} ; 8 \% \mathrm{~S} ; 14 \% \mathrm{CaO}$ and $3.5 \% \mathrm{MgO}$. It is also po-

Table 1. Results of selected determinations in waste gypsum samples

\begin{tabular}{|l|c|}
\hline Determination & Value \\
\hline Weight loss at $105^{\circ} \mathrm{C}$, wt. $\%$. & 23.81 \\
\hline Weight loss at $400^{\circ} \mathrm{C}$, wt. $\%$ & 39.34 \\
\hline Weight loss at $1000^{\circ} \mathrm{C}$, wt. $\%$ & 45.96 \\
\hline $\mathrm{SO}_{3}$, wt. $\%$ & 31.60 \\
\hline $\mathrm{CaO}_{\text {tot. }}$ wt. $\%$ & 20.09 \\
\hline $\mathrm{CaO}_{\text {w.s. }}$ wt. $\%$ & 8.45 \\
\hline $\mathrm{MgO}_{\text {tot. }}$ wt.\% & 5.19 \\
\hline $\mathrm{MgO}_{\text {w.s. }}$ wt. $\%$ & 3.48 \\
\hline
\end{tabular}

tot. - total

w.s. - soluble in water.

Table 2. Parameters of laboratory granulation test

\begin{tabular}{|l|c|}
\hline Parameter & Value \\
\hline Gypsum (raw) content in the pulp, wt. \% & 58.5 \\
\hline Urea content in the pulp, wt. $\%$ & 41.5 \\
\hline Water content in the pulp, wt. $\%$ & 22.4 \\
\hline Mass ratio of the pulp to the dried product & $1: 2.2$ \\
\hline Water content in the granulation mixture, wt. $\%$ & 7.0 \\
\hline
\end{tabular}

ssible to take into consideration other compositions of the fertilizer, richer or poorer in nitrogen, by changing the dose of the urea.

As a result of the laboratory tests it was concluded that mixing of the urea with the waste gypsum leads to the formation of pulp that can undergo granulation already at the temperature of $30^{\circ} \mathrm{C}$ upon the lapse of 15 minutes. Increasing the temperature to $60^{\circ} \mathrm{C}$ results in faster liquefaction of the reaction mixture. During the formation of the pulp samples were collected to determine of the degree of conversion of the urea into the form of adducts and the particles hardness of the dried and crushed pulp was measured. It was stated that after 60 minutes from the commencement of the process conducted at the temperature of 30 and $60^{\circ} \mathrm{C}$, the degree of conversion of the urea exceeded $90 \%$ and the hardness of particles was at the level of $30 \mathrm{~N} / \mathrm{gran}$.

At the laboratory site the granulated product (Table 2) was also produced. $855 \mathrm{~g}$ of the pulp as fed to the granulator at the temperature of $30^{\circ} \mathrm{C}$ and the $1870 \mathrm{~g}$ of dried product with identical composition was dosed gradually until the granulate was formed. Dosing was completed after 30 minutes. The obtained granules were characterised with the medium hardness of 34.8 $\mathrm{N} / \mathrm{gran}$. The laboratory results allow to assume that the product obtained on a larger scale will possess good physicochemical properties and its granulation should not cause problems.

Taking into account the experience gained in the laboratory tests, it was established that the process of the production of the fertilizer on the basis of the waste gypsum and urea must include the following operations: mixing of the waste gypsum of urea, granulation of the prepared pulp, drying of the granulate, sieving (recycle of undersize and ground oversize product to the granulation), cooling and potential conditioning of the fertilizer. According to the assumed concept, the pilot scale trial of fertilizer N-S-Ca-Mg 25-8-14-3.5 production was conducted. The parameters of the trial have been presented in Table 3. As a result of the trial, the fertilizer with the expected composition and high degree of urea conversion into the form of the adduct was obtained (Table 4). The hardness of the product granules directly upon formation was $29 \mathrm{~N} / \mathrm{gran}$. and it increased to 40 $\mathrm{N} /$ gran. within 2 months. The hardness of the granules from the sample additionally dried at $105^{\circ} \mathrm{C}$ (mass loss $2.32 \%$ ) increased to $60.5 \mathrm{~N} /$ gran.

The evaluation of hygroscopicity (Fig. 1) indicated that the samples exposed to air with controlled relative humidity increased their mass from $0.5 \%$ (relative hu-

Table 3. Parameters of pilot plant granulation test

\begin{tabular}{|c|c|c|}
\hline Parameter & \multicolumn{2}{|c|}{ Value } \\
\hline $\begin{array}{l}\text { Gypsum (raw) content in the pulp, } \\
\text { wt.\% }\end{array}$ & \multicolumn{2}{|c|}{57.3} \\
\hline Urea content in the pulp, wt.\% & \multicolumn{2}{|c|}{42.7} \\
\hline Water content in the pulp, wt.\% & \multicolumn{2}{|c|}{23.1} \\
\hline Stream of the feed, $\mathrm{kg} / \mathrm{min}$ & \multicolumn{2}{|c|}{0.5} \\
\hline Stream of the recycle, $\mathrm{kg} / \mathrm{min}$ & \multicolumn{2}{|c|}{$2.4-3.6$} \\
\hline Pulp temperature, ${ }^{\circ} \mathrm{C}$ & \multicolumn{2}{|c|}{60} \\
\hline \multirow{2}{*}{$\begin{array}{l}\text { Operating temperature of the dryer } \\
\text { (counter-current), }{ }^{\circ} \mathrm{C}\end{array}$} & entry & $\begin{array}{r}1 \\
15\end{array}$ \\
\hline & exit & $\begin{array}{r}1 \\
50\end{array}$ \\
\hline $\begin{array}{l}\text { Product temperature on the exit } \\
\text { from the dryer, }{ }^{\circ} \mathrm{C}\end{array}$ & \multicolumn{2}{|c|}{110} \\
\hline
\end{tabular}


Table 4. Properties of fertilizer prepared at pilot plant granulation test

\begin{tabular}{|c|c|c|c|}
\hline No. & Determination & \multicolumn{2}{|c|}{ Value } \\
\hline 1 & $\mathrm{~N}$ content, wt. $\%$ & \multicolumn{2}{|c|}{24.78} \\
\hline 2 & S content, wt. \% & \multicolumn{2}{|c|}{8.78} \\
\hline 3 & $\mathrm{CaO}$ content, wt. $\%$ & \multicolumn{2}{|c|}{14.51} \\
\hline 4 & MgO content, wt. $\%$ & \multicolumn{2}{|c|}{3.73} \\
\hline 5 & Mass loss at $105^{\circ} \mathrm{C}, \%$ mas. & \multicolumn{2}{|c|}{3.89} \\
\hline 6 & Degree of urea conversion into the adduct form, $\%$ & \multicolumn{2}{|c|}{86.9} \\
\hline \multirow{3}{*}{7} & \multirow{3}{*}{ Granules hardness ( fraction $2.5-3.15 \mathrm{~mm}$ ), N/gran. } & After production & 29.0 \\
\hline & & After 5 days & 31.0 \\
\hline & & After 62 days & 40.0 \\
\hline 8 & Eqivalent diameter acc. to Lev, $\mathrm{mm}$ & \multicolumn{2}{|c|}{3.23} \\
\hline
\end{tabular}

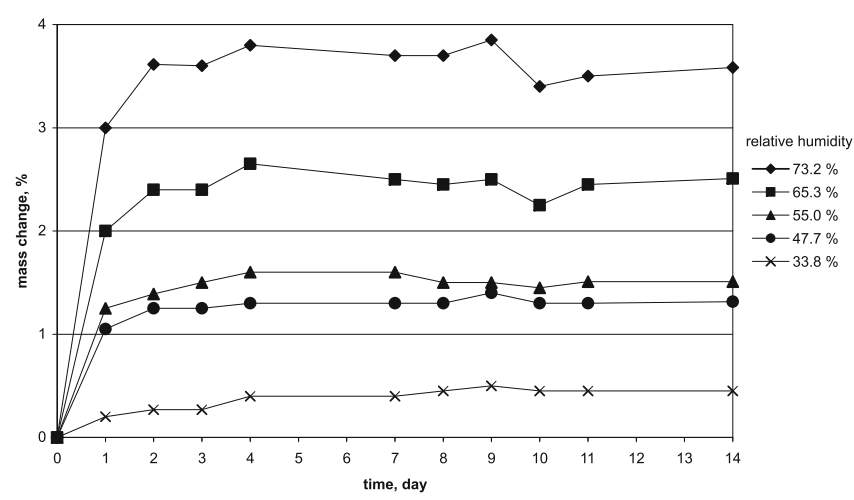

Figure 1. Changes in mass of fertilizer prepared during pilot plant granulation test exposed to atmospheres with varied relative humidity

midity $33.8 \%$ ) to $3.5 \%$ (relative humidity $73.2 \%$ ) within two days. After further 10 days, there were no significant changes in the mass of the samples.

\section{CONCLUSIONS}

On the basis of the conducted tests it was concluded that in the conditions of Chemical Company Alwernia S.A. the by-product gypsum can be used for the production of the granulated fertilizers. According to the concept, the obtained fertilizers would be of NSCaMg type, with urea as the nitrogen source. The calcium and magnesium sulphates in the waste will be bounded in the fertilizer in the form of adducts of $\mathrm{CaSO}_{4} \cdot 4 \mathrm{CO}\left(\mathrm{NH}_{2}\right)_{2}$ and $\mathrm{MgSO}_{4} \cdot \mathrm{CO}\left(\mathrm{NH}_{2}\right)_{2} \cdot 3 \mathrm{H}_{2} \mathrm{O}$. The test results confirmed the possibility of obtaining the fertilizer consisting of $3,5 \% \mathrm{~N} ; 8 \% \mathrm{~S} ; 14 \% \mathrm{CaO}$ and $3.5 \% \mathrm{MgO}$, characterised by appropriate physical properties.

\section{LITERATURE CITED}

1. Chojnacka, K., Barańska, M., Górecka, H. \& Górecki, H. (2006). Utilization of animal bones, feather and wood ash in the making of mineral fertilizers. Przem. Chem. 85(8-9), 1256-1259 (in Polish).

2. Weigand, H., Bertau, M., Hubner, W., Bohndick, F. \& Bruckert, A. (2013). RecoPhos: Full-scale fertilizer production from sewage sludge ash. Waste Manage. 33(3), 540-544. DOI: 10.1016/j.wasman.2012.07.009.

3. Rominski, M., Michalak, P., Jaskulski, D. \& Jaskulska, I. (2011). Technology for manufacturing granulated magnesium fertilizers with the use of wastes from chlorine production, Przem. Chem. 90 (4), 628-630 (in Polish).

4. Malinowski, P., Olech, M., Sas, J., Wantuch, W., Biskupski, A., Urbańczyk, L., Borowik, M. \& Kotowicz, J. (2010). Production of compound mineral fertilizers as a method of utilization of waste products in Chemical Company Alwernia S.A., Pol. J. Chem. Tech. 12(3), 6-9. DOI: 10.2478/v10026-010-0024-z.
5. Grzmil, B. \& Kowal, D. (2006). Preparation of urea-based multicomponent fertilizers - a comparative study, Przem. Chem. 85(8-9), 823-826 (in Polish).

6. Sulajmankulov, K. 1980. Atlas diagramm rastvorimosti trojnyh vodno-solevyh karbamidnyh sistem, Izdatielstvo ILIM, Frunze.

7. Biskupski, A., Malinowski, P., Igras, J., Borowik, M., Podleśna, A. \& Schab, S. (2009). Nitrogen granular fertilizers - current status and perspectives of development in Poland. Przem. Chem. 12, 1337-1341 (in Polish).

8. Regulation (EC) No 2003/2003 of the European Parliament and of the Council of 13 October 2003 relating to fertilizers. Official Journal of the European Union L 304/1.

9. Pawlikowski, S. \& Szymonik, S. (1959). About the methodology of determining the hygroscopicity. Przem. Chem. 8, 598-599 (in Polish).

10. Malinowski, P., Biskupski, A. \& Głowiński, J. (2007). Preparation methods of calcium sulphate and urea adduct. Pol. J. Chem. Tech. 9(4), 111-114. DOI: 10.2478/v10026-007-0102-z. 